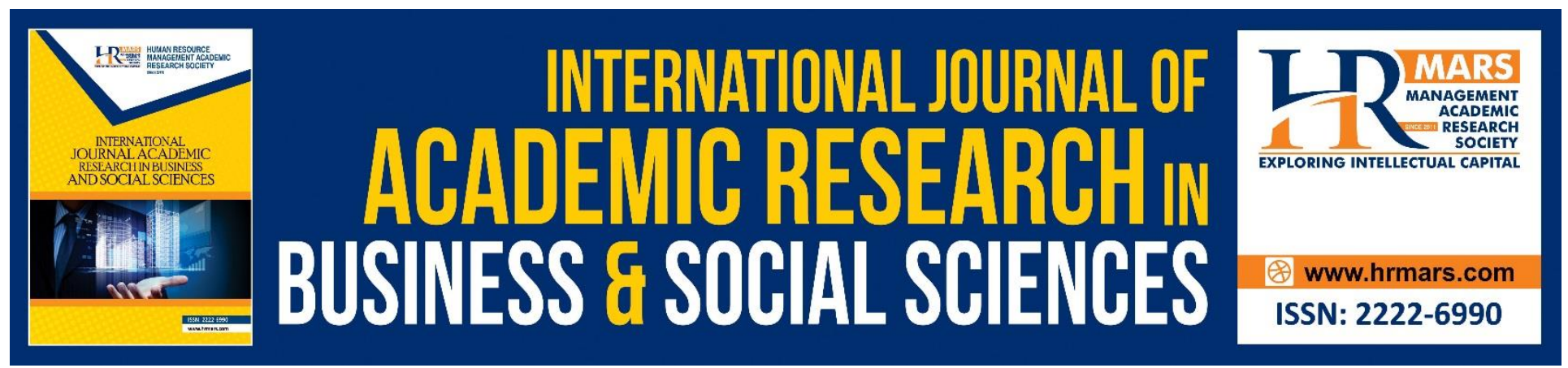

\title{
School Leaders Support towards the Use of Frog VLE Application among Islamic Education Teachers
}

Mohd Faiz Mohd Baharan, Mohd Nor Mamat, Zawawi Temyati \& Kanniga Malar Mohan

To Link this Article: http://dx.doi.org/10.6007/IJARBSS/v10-i7/7611 DOI:10.6007/IJARBSS/v10-i7/7611

Received: 17 April 2020, Revised: 04 May 2020, Accepted: 20 June 2020

Published Online: 12 July 2020

In-Text Citation: (Baharan et al., 2020)

To Cite this Article: Baharan, M. F. M., Mamat, M. N., Temyati, Z., \& Mohan, K. M. (2020). School Leaders Support towards the Use of Frog VLE Application among Islamic Education Teachers. International Journal of Academic Research in Business and Social Sciences, 10(7), 808-817.

Copyright: (C) 2020 The Author(s)

Published by Human Resource Management Academic Research Society (www.hrmars.com)

This article is published under the Creative Commons Attribution (CC BY 4.0) license. Anyone may reproduce, distribute, translate and create derivative works of this article (for both commercial and non-commercial purposes), subject to full attribution to the original publication and authors. The full terms of this license may be seen

at: http://creativecommons.org/licences/by/4.0/legalcode

\section{Vol. 10, No. 7, 2020, Pg. 808 - 817}

Full Terms \& Conditions of access and use can be found at http://hrmars.com/index.php/pages/detail/publication-ethics 


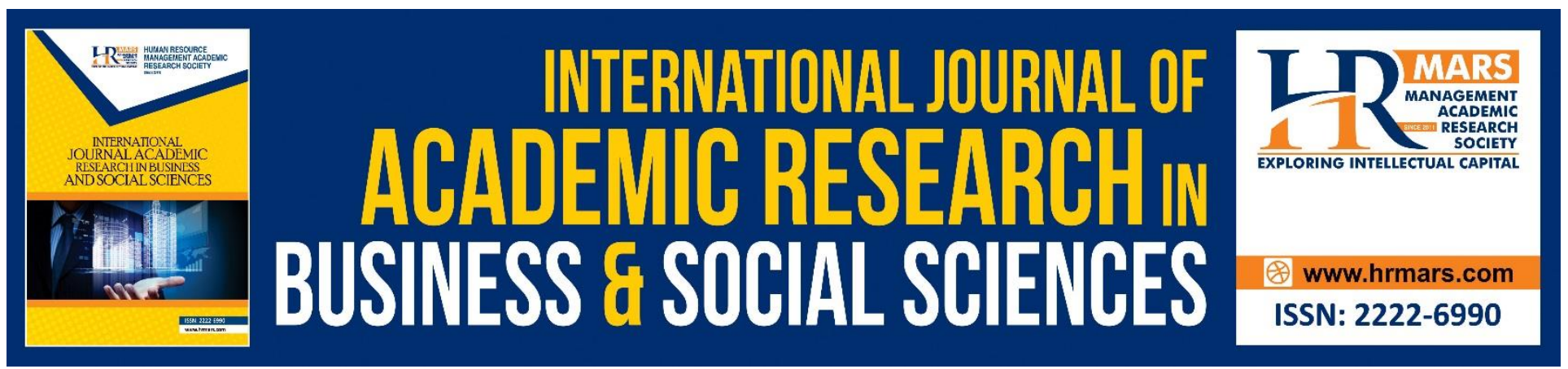

\title{
School Leaders Support towards the Use of Frog VLE Application among Islamic Education Teachers
}

\author{
Mohd Faiz Mohd Baharan, Prof. Madya Dr. Mohd Nor Mamat, \\ Zawawi Temyati \& Kanniga Malar Mohan \\ Academy of Contemporary Islamic Studies, UiTM Shah Alam Selangor, Malaysia \\ University of Malaya, Malaysia \\ Email: fazries@yahoo.com.my
}

\begin{abstract}
School leaders play an important role in transforming schools towards excellence in education. The application of Frog VLE is one of the educational transformations introduced to nearly 10,000 schools in Malaysia. However, the use of this application is still at a low level based on scientific studies carried out by the researchers. In this regard, this study was conducted to evaluate the support of school leaders towards the readiness of Islamic Education teachers towards the use of Frog VLE applications in schools, especially primary schools. This study conducted quantitative method using observation and questionnaire instruments. A total number of 367 respondents completed their questionnaire and analyzed through SPSS 23.0. The results showed that the support level of school leaders was high at mean $=3.82$ and standard deviation $=0.29$. The findings also found significant correlation between the support of school leaders and the willingness of Islamic education teachers at $r=0.37$. Hence, it is recommended that school leaders need to increase the encouragement level in the form of motivation, monitoring and activating the Islamic Education teachers to use Frog VLE frequently, so that this application will be consistent and expanded.
\end{abstract}

Keywords: School leader, Frog VLE application, Islamic Education Teacher.

\section{Introduction}

The education system in Malaysia is undergoing a transformation from time to time to ensure the quality of education to be high and able to compete with other global countries. Quality education is a key feature in determining the level of education system of a developing country (Mustafa \& Miskon, 2011). The transition of knowledge through various forms of education has built the universality and global society through navigation, trade, religious dissemination and information communication technology (Nor \& Hussin, 2013). The paradigm shift that has been done by the community has given a new transformation in the era of today's technological education. 
INTERNATIONAL JOURNAL OF ACADEMIC RESEARCH IN BUSINESS AND SOCIAL SCIENCES Vol. 10, No. 7, July, 2020, E-ISSN: 2222-6990 @ 2020 HRMARS

Along with the willingness of the Ministry of Education Malaysia (MOE) to encourage teaching and learning involving technology will indirectly provide students with the challenge of learning the 21st century (PAK-21) (Kementerian Pendidikan Malaysia, 2013). The change in the form of learning from traditional methods to learning which utilizes modern technology (Dolah, 2013) is seen to promote the active relationship between each subject with each individual student for learning purpose (Abel et al., 2013).

Islamic education teachers are drivers of change should have basic domains such as subject knowledge, skills to teaching and information technology skills in meeting the borderless world. In the educational process, Islamic education teachers are one of the people who have been tasked in achieving the country's desire and aspiration in order to build the minds of first class young generation. This is appropriate with the Islamic Education Philosophy that emphasize the ongoing concerted effort in conveying knowledge for self-development, building self-esteem and being an example based on al-Quran and as-Sunnah (Noornajihan Jaafar \& Ab.Halim Tamuri, 2013).

Virtual learning of Frog VLE is regarded as an online form of education that enables students to develop and acquire their learning and knowledge skills as well as to enhance motivation in learning (Barker \& Gossman, 2013). According to (Murat et al., 2017) Frog VLE application is an internet platform based on cloud that allows users to access anytime at anywhere. This application allows teachers to add new teaching materials, share teaching materials with other teachers, use existing teaching materials and process teaching materials to be used during teaching sessions in class according to the level of students' thoughts. In this regard, Islamic education teachers play a role to assist and mobilize current educational changes to face the globalization challenges of PAK-21. According to Peng, Soon, \& Daud (2016) the VLE system has changed the paradigm and transformation of today's education and the way in which interactions between teachers and pupils are in school.

This application is a 1Bestarinet Service Project (1Bestarinet) implemented in collaboration with YTL Communication Sdn. Bhd to replace and improve the ICT network system in schools which have been expired on 31 December 2010 (Kementerian Pendidikan Malaysia, 2010). The project has shown that nearly 10,000 schools across Malaysia are equipped with high speed internet access and virtual learning platforms through the application of high-speed Internet networks and access to world-class integrated education solutions.

\section{Problem Statement}

Ministry of Finance (2013) also acknowledged that this 1Bestarinet Service Project has not yet achieved its targeted objective. An audit conducted in October 2013 to April 2014 found that the level of Frog VLE usage among teachers was very low with an average usage of only $0.57 \%$ to $4.69 \%$. The calculation of the daily usage of Frog VLE is based on the assumption that the daily number of users logged is equal to the number of users who access Frog VLE. This percentage is likely to be much lower as the amount of logs recorded in the system does not represent the actual number of users accessing the Frog VLE following one user can log in Frog VLE more than once per day. This situation makes worrisome and negatively affecting national spending.

This is also supported in the study that conducted by Azlah \& Fariza (2014) which finds usage data from November 2012 to February 2013 using Frog VLE among teachers is very less and weak. 
Additionally, in the earliest January the KPM issued a bill letter of $1 / 2015$ by urging school principals and administrators to take appropriate action by ensuring that the use of Frog VLE at schools is conducted optimally (Kementerian Pendidikan Malaysia, 2015).

In line with current educational needs that give priority to student-centered teaching and PAK-21. Hence, this study should be conducted on the teachers of Islamic Education in primary schools to increase the use of Frog VLE applications in schools. This is because, Islamic Education teachers are the dominant teachers in primary schools based on a ratio of 1: 15 which has the evidenced through 'Surat Pekeliling Ikhtisas KPM Bilangan 2' year 2015 related on 'Pelaksanaan Norma Baharu Guru Pendidikan Islam Sekolah Rendah, KPM'.

\section{Research Objective}

This study is conducted to achieve the following objectives;

i. To identifying the support level of school leaders in the use of Frog VLE applications,

ii. To identifying the level of readiness to use Frog VLE application among Islamic education teachers,

iii. To evaluate the relationship between the support of school leaders and the willingness to use the Frog VLE application among Islamic education teachers.

\section{Research Questions}

This study was conducted to answer the following questions;

i. What is the level of school leader support for the use of Frog VLE application?

ii. What is the level of willingness to use the VLE Frog application among Islamic Education teachers?

iii. Is there a significant relationship between the support of school leaders and the willingness to use the Frog VLE application among Islamic education teachers?

\section{Research Methodology}

This study is a quantitative study of survey types. The data needed for this study were collected through a questionnaire comprising several constructs, namely the support of school leaders to use Frog VLE application and the construct of willingness to use Frog VLE application among Islamic education teachers. The research instrument used in this study is a form of questionnaire in Bahasa Malaysia which contains three sections. The questionnaires have been used ordinal measurement scale and 5 point Likert scale. The Likert scale used represents $1=$ Strongly Disagree, $2=$ Disagree, 3 $=$ Unsure, $4=$ Agree and $5=$ Strongly Agree. The distribution of the items and the reference sources for constructing the items according to the section shown in Table 1. 
INTERNATIONAL JOURNAL OF ACADEMIC RESEARCH IN BUSINESS AND SOCIAL SCIENCES Vol. 10, No. 7, July, 2020, E-ISSN: 2222-6990 @ 2020 HRMARS

Table 1: Questionnaire Determination

\begin{tabular}{llll}
\hline Section & Issue & Item & Reference sources \\
\hline$A$ & Respondent Demographics & A1-A4 & $\begin{array}{l}\text { Self-built by researchers } \\
\text { Combined of research build and modified }\end{array}$ \\
$B$ & $\begin{array}{l}\text { Willingness of use Frog VLE } \\
\text { application }\end{array}$ & $B 1-B 5$ & $\begin{array}{l}\text { from Ummu Salma \& Fariza (2014) } \\
\text { School Leaders Support }\end{array}$ \\
C C1-C9 & $\begin{array}{l}\text { Combined of research build and modified } \\
\text { from Nik Aida Suria Nik Zulkifli Ami (2016) }\end{array}$ \\
\hline
\end{tabular}

Question items have been tested on the reliability and validity of two aspects, namely through the validity of the experts and carry out the confirmatory factor analysis (CFA) so that the instruments used are appropriate and able to answer the research questions (Ghafar, 2003).

Table 2: Reliability Coefficient Value

\begin{tabular}{lll}
\hline Contruct & Number of items & Reliability coefficient \\
\hline Willingness of use Frog VLE application & 5 & 0.77 \\
School Leaders Support & 9 & 0.80 \\
\hline
\end{tabular}

Based on Table 2, the construct of willingness to use Frog VLE application has stated reliability coefficient value of 0.77 with 5 items. At the same time, the construct of School Leaders Support has been stated the reliability coefficient value of 0.80 with a total items of 9 . Because of the reliability coefficient value exceeds 0.60 then it is very good and is considered to have high reliability and acceptability (Darusalam \& Hussin, 2016).

The researcher has also obtained the validity of the experts from 3 experts in Islamic Education and e-learning such as lecturers from University of Malaya, Universiti Pendidikan Sultan Idris and Assistant Director of Division of Education Technology KPM.

This study used a sample of 367 Islamic Education teachers who are teaching in primary schools in Selangor. In order to ensure that the research is conducted smoothly and perfectly, the researcher has followed the study procedure which involves systematic measures being planned and followed during this study. After a double confirmation that all returned questionnaires are fully answered, the questionnaire instrument has been processed to obtain reliability through reliability coefficients. All research data were analysed using Statistical Packages for Social Sciences (SPSS) version 23.0.

\section{Data Analysis}

\section{Respondent Demographics}

The sample distribution was 367 primary school Islamic teachers in Selangor. Respondent background analysis involves demographics such as school location, gender and total teaching time of the week. The respondents' demographic summary is as stated in the table 3: 
INTERNATIONAL JOURNAL OF ACADEMIC RESEARCH IN BUSINESS AND SOCIAL SCIENCES Vol. 10, No. 7, July, 2020, E-ISSN: 2222-6990 @ 2020 HRMARS

Table 3: Profile of Research Respondent

\begin{tabular}{llll}
\hline Demographics & Categories of Respondents & Frequency & Percentage\% \\
\hline School location & Urban & 187 & 51.0 \\
& Rural & 180 & 49.0 \\
\hline Gender & Male & 84 & 22.9 \\
& Female & 283 & 77.1 \\
\hline Level of education & SPM / STPM & 6 & 1.6 \\
& Diploma & 11 & 3.0 \\
& Bachelor's Degree & 336 & 91.6 \\
& Master's Degree & 14 & 3.8 \\
& Doctor of Philosophy (PhD) & 0 & 0.0 \\
\hline
\end{tabular}

School location of the respondents showed that 187 people (51\%) were teaching in urban areas and 180 people (49\%) teachers in rural areas. Respondents consisted of 84 male teachers $(22.9 \%)$ and $283(77.1 \%)$ of female teachers. From the aspect of the respondents' level of education, 6 teachers (1.6\%) that had SPM/STPM, 11 teachers (3\%) had Diplomas, 336 teachers (91.6\%) had a Bachelor's Degree, 14 (3.8\%) teachers have Master's Degree and no one as stated as has Doctorate of Philosophy (PhD). In summary, respondents gave good feedback in this section.

\section{The Willingness to use the Frog VLE Application among ISLAMIC EDUCATION TEACHERS}

Table 4: Distribution of willingness to use of Frog VLE application

\begin{tabular}{|c|c|c|c|c|c|c|c|c|}
\hline \multirow{2}{*}{ ITEM } & \multirow{2}{*}{ STATEMENT } & $S D$ & $D$ & NS & $A$ & $S A$ & \multirow{2}{*}{ MEAN } & \multirow{2}{*}{$S D$} \\
\hline & & \multicolumn{5}{|l|}{$\%$} & & \\
\hline$B 1$ & $\begin{array}{l}\text { I use Frog VLE in teaching Islamic } \\
\text { Education. }\end{array}$ & - & 0.5 & 10.6 & 84.7 & 4.1 & 3.92 & 0.40 \\
\hline$B 2$ & $\begin{array}{l}\text { I use Frog VLE to plan Islamic } \\
\text { Education teaching. }\end{array}$ & - & 0.8 & 16.9 & 79.0 & 3.3 & 3.85 & 0.46 \\
\hline B3 & $\begin{array}{l}\text { I use Frog VLE in providing teaching } \\
\text { materials. }\end{array}$ & - & 0.3 & 16.6 & 79.8 & 3.3 & 3.86 & 0.44 \\
\hline B4 & $\begin{array}{l}\text { I built a dashboard site for teaching } \\
\text { Islamic Education. }\end{array}$ & - & 2.5 & 22.9 & 71.7 & 3.0 & 3.75 & 0.54 \\
\hline B5 & $\begin{array}{l}\text { I am preparing task to my students by } \\
\text { using Frog VLE. }\end{array}$ & - & 1.6 & 19.1 & 75.2 & 4.1 & 3.82 & 0.51 \\
\hline \multicolumn{7}{|c|}{ Total Mean } & 3.83 & 0.30 \\
\hline
\end{tabular}

Instructions by Vagias (2006): SD (Strongly Disagree), D (Disagree), NS (Not Sure), A (Agree), SA (Strongly Agree)

Mean Value by Tschannen Moran \& Gareis (2004): 1.00-1.80 (very low), 1.81-2.60 (low), 2.61-3.40 (modest), 3.41-4.20 (height), 4.21-5.00 (very height)

Table 4 shows the distribution that practice of Frog VLE application among Islamic Education teachers at a high level which is at the overall mean of 3.83 and standard deviation of 0.29 . All items are at high mean values and B1 items I use Frog VLE in teaching Islamic Education is the highest mean item value at (mean $=3.92, S D=0.40$ ) while B4 I built a dashboard site for teaching Islamic Education is the lowest mean value of (mean $=3.75, \mathrm{SD}=0.54$ ). In summary, Islamic Education teachers in the 
INTERNATIONAL JOURNAL OF ACADEMIC RESEARCH IN BUSINESS AND SOCIAL SCIENCES Vol. 10, No. 7, July, 2020, E-ISSN: 2222-6990 @ 2020 HRMARS

state of Selangor have been using Frog VLE applications in classroom teaching. Teachers of Islamic Education have the knowledge and identify each application in Frog VLE and are ready to use VLE Frog application in teaching at school.

School Leaders Support in the use of Frog VLE application among Islamic Education Teachers

TABLE 5: Distribution of School Leader Support in the use of Frog VLE application

\begin{tabular}{|c|c|c|c|c|c|c|c|c|}
\hline \multirow{2}{*}{ ITEM } & \multirow{2}{*}{ STATEMENT } & $S D$ & $D$ & NS & $A$ & SA & \multirow{2}{*}{ MEAN } & \multirow{2}{*}{$S D$} \\
\hline & & $(\%)$ & & & & & & \\
\hline$C 1$ & $\begin{array}{l}\text { School leaders give me the } \\
\text { information about teaching } \\
\text { techniques that can help improve } \\
\text { the quality of Frog VLE-oriented } \\
\text { teaching. }\end{array}$ & - & 0.8 & 15.0 & 77.7 & 6.5 & 3.90 & 0.49 \\
\hline$C 2$ & $\begin{array}{l}\text { My school leaders often monitor the } \\
\text { use of Frog VLE teachers. }\end{array}$ & - & 1.9 & 24.8 & 67.6 & 5.7 & 3.77 & 0.57 \\
\hline C3 & $\begin{array}{l}\text { School leaders help me to adapt the } \\
\text { curriculum in teaching planning } \\
\text { through Frog VLE. }\end{array}$ & - & 1.4 & 21.5 & 76.8 & 0.3 & 3.76 & 0.46 \\
\hline C4 & $\begin{array}{l}\text { School leaders make sure that I have } \\
\text { the appropriate space for Frog VLE- } \\
\text { oriented teaching activities. }\end{array}$ & - & 1.4 & 23.2 & 73.3 & 2.2 & 3.76 & 0.50 \\
\hline$C 5$ & $\begin{array}{l}\text { School leaders encourage teachers } \\
\text { to use Frog VLE in their teaching in } \\
\text { classroom. }\end{array}$ & - & - & 5.4 & 85.6 & 9.0 & 4.04 & 0.38 \\
\hline C6 & $\begin{array}{l}\text { My school leaders always give me } \\
\text { the motivation to use Frog VLE in } \\
\text { teaching. }\end{array}$ & - & 0.3 & 11.4 & 79.6 & 8.7 & 3.97 & 0.46 \\
\hline$C 7$ & $\begin{array}{l}\text { My school leaders provided } \\
\text { adequate equipment for Frog VLE } \\
\text { based teaching. }\end{array}$ & - & 3.5 & 19.6 & 71.9 & 4.9 & 3.78 & 0.58 \\
\hline C8 & $\begin{array}{l}\text { My school leaders provided } \\
\text { adequate infrastructures for Frog } \\
\text { VLE based teaching. }\end{array}$ & - & 2.7 & 24.3 & 67.8 & 5.2 & 3.75 & 0.59 \\
\hline C9 & $\begin{array}{l}\text { My school leaders use the Frog VLE } \\
\text { facility in dealing with the school } \\
\text { official matters. }\end{array}$ & - & 3.8 & 34.1 & 55.6 & 6.5 & 3.65 & 0.66 \\
\hline
\end{tabular}

Instructions by Vagias (2006): SD (Strongly Disagree), D (Disagree), NS (Not Sure), A (Agree), SS (Strongly Agree)

Mean Value by Tschannen Moran \& Gareis (2004): 1.00-1.80 (very low), 1.81-2.60 (low), 2.61-3.40 (modest), 3.41-4.20 (height), 4.21-5.00 (very height) 
INTERNATIONAL JOURNAL OF ACADEMIC RESEARCH IN BUSINESS AND SOCIAL SCIENCES Vol. 10, No. 7, July, 2020, E-ISSN: 2222-6990 @ 2020 HRMARS

Table 5 shows the distribution of school leaders support in the use of Frog VLE application among Islamic Education teachers at a high level which is at the overall mean of 3.82 and a standard deviation of 0.30. All items are at high mean value and C5 items School leaders encourage teachers to use Frog VLE in their teaching in classroom is the highest mean item value at (mean $=4.04, S D=$ 0.38) while C9 item My school leaders use the Frog VLE facility in dealing with the school official matters are items that have the lowest mean value of (mean $=3.65, S D=0.66)$. In summary, Islamic Education teachers in the state of Selangor have always received support from the school leaders or administration in integrating teaching through Frog VLE applications.

The Relationship between the Support of School Leaders and the Willingness in the Use of Frog VLE Applications among Islamic Education Teachers

Table 6: The value of the relationship between the support of school leaders and the willingness of teacher to use the Frog VLE app

\begin{tabular}{|c|c|c|c|}
\hline & & $\begin{array}{l}\text { School Leaders } \\
\text { Support }\end{array}$ & $\begin{array}{l}\text { Willingness of } \\
\text { Teacher }\end{array}$ \\
\hline \multirow[t]{3}{*}{ School Leaders Support } & Pearson Correlation & 1 & $.374 * *$ \\
\hline & Sig (2-tailed) & & .000 \\
\hline & $N$ & 367 & 367 \\
\hline \multirow[t]{3}{*}{ Willingness of Teacher } & Pearson Correlation & $.374 * *$ & 1 \\
\hline & Sig (2-tailed) & .000 & \\
\hline & $N$ & 367 & 367 \\
\hline
\end{tabular}

**. Relationships Are Significant is 0.01 (2-tailed)

Correlation Coefficient Value by Hinkle, Wiersma \& Jurs (2003) : 0.91-1.00 (very strong), 0.75-0.90 (strong), 0.51-0.70 (modest), 0.31-0.50 (weak), 0.01-0.30 (very weak), 0.00 (no correlation)

Table 6 shows the relationship between the support of school leaders and the willingness in the use of frog VLE applications among Islamic education teachers. The findings of the Pearson correlation analysis show that there is a weak relationship between the school leader's support and the willingness to use the Frog VLE application among Islamic Education teachers where the correlation coefficient value is $r=.374^{* *}, \mathrm{p}<.000$. Because Pearson's relationship is positive then this means the higher the support of school leaders, the higher the use of Frog VLE application in schools among Islamic Education teachers. As a result, every school leaders need to show the encouragement in the form of motivation, observation, activating the Islamic Education teachers so that the frequency of using Frog VLE will be consistent and competitive.

\section{Discussion and Recommendation}

From the findings, the Islamic Education teachers received positive feedback from the school leaders since the support of school leaders was high and significant in schools, especially primary schools. The finding also found that there was a weak and significant relationship between the support of school leaders and the willingness to use the Frog VLE application in schools among Islamic Education teachers in schools. This situation illustrates that the need for support from school leaders should be given to every teacher, especially the Islamic Education teacher. School leaders play a key role in 
supervise, making observations, motivating teachers, and providing guidance in order to achieve the goals and mission of the school outlined (Mahmood, 2005).

The findings are supported in the study made by David (2002) of eight primary schools and eight high schools in United States. The findings show that, there is a good and positive relationship between the leadership and the support of leaders with the teaching of teachers in schools. The findings also show that, the involvement of school leaders as instructional leaders is crucial in ensuring the effective use of Frog VLE applications in schools.

Therefore, the researcher proposes several suggestions to improve the use of Frog VLE application among primary school Islamic Education teachers. First, Islamic Education teachers should take the challenge and strive to improve their knowledge and skills especially in information technology and communication. Secondly, the school leaders should provide encouragement, motivation and positive stimulus to Islamic Education teachers who implement teaching and learning using information technology, especially through Frog VLE application. Thirdly, the roles of the District Education Office, State Education Department and Ministry of Education through the Islamic Education Division to intensify the form of training and guidance to Islamic Education teachers on the awareness of the use of information technology in teaching in the classroom, especially Frog VLE application maximally. According to Cuban (2003), as long as teachers do not change the pattern and practice of teaching, so that any effort to integrate the use of information technology in teaching and learning will fail.

\section{Summary}

School is a dynamic institution and organization, according to changes and is always relevant to current educational developments. School leaders deserve a situation that makes him/her more acceptable and appreciated through good rapport and his ability to influence his followers towards achieving school goals and visions (Ouchi, 1980). This creates a personal relationship always exists at a good level between the headmasters/headmistress and the teachers in the school. The form of contact that can be used includes motivation, guidance, advice and appreciation to teachers who implement their teaching with Frog VLE application.

Therefore, the role and support of the headmasters/headmistress has significant relationship with teaching and willingness of Islamic Education teachers in schools to practice Frog VLE application in the teaching of Islamic Education subjects. This clearly demonstrates that the support factor of school administrators is essential and is one of the main factors for the use of Frog VLE applications particularly in primary schools.

The basic features of a great Islamic Education teacher include the teaching and learning, the personality, the mastery of knowledge and skills, the integration of information technology and the positive environment of Islamic Education teachers (Jasmi, 2011). This is a major task that must be realized by an Islamic Education teacher in the current era of information technology explosions.

\section{References}

Abel, R., Brown, M., \& Suess, J. (2013). New Architecture For Learning. Educause, 2(9), 88-102.

Ami, N. A. S. N. Z. (2016). Hubungan Sokongan Guru Besar, Efikasi Kendiri dan Efikasi Kolektif Dengan Komitmen Kerja Guru Pendidikan Khas. Universiti Kebangsaan Malaysia.

Baharan, M. F. M., Mamat, M. N., Temyati, Z., \& Mohan, K. M. (2020). School Leaders Support towards the Use of Frog VLE Application among Islamic Education Teachers. International 
INTERNATIONAL JOURNAL OF ACADEMIC RESEARCH IN BUSINESS AND SOCIAL SCIENCES

Vol. 10, No. 7, July, 2020, E-ISSN: 2222-6990 @ 2020 HRMARS

Journal of Academic Research in Business and Social Sciences, 10(7), 638-648.

Barker, J., \& Gossman, P. (2013). The Learning Impact of A Virtual Learning Environment : Student's

View. Teacher Education Advancement Network Journal, 5(2), 19-38.

Darusalam, G., \& Hussin, S. (2016). Metodologi Penyelidikan Dalam Pendidikan : Amalan dan

Analisis Kajian. Penerbit Universiti Malaya.

Dolah, W. M. R. W. (2013). Penerapan Teknologi Dalam Pendidikan. Kolokium ICT Dalam Pendidikan 2013 : Kepimpinan Pengurusan ICT Dalam Pendidikan Abad Ke-21.

Ghafar, M. N. A. (2003). Rekabentuk Tinjauan Soal Selidik Pendidikan. Universiti Teknologi Malaysia.

Hinkle, D. E., Wiersma, W., \& Jurs, S. G. (2003). Applied Statistic For The Behavioral Sciences (5th ed.). Houghton Mifflin.

Jasmi, K. A. (2011). Pendidikan Islam: Cabaran di Alaf Baru. Seminar Pendidikan Islam, 1-15.

Kementerian Kewangan Malaysia. (2013). laporan Audit Negara tahun 2013.

Kementerian Pendidikan Malaysia. (2010). Rancangan Malaysia Ke-10: Bab 5: Membangun dan

Mengekalkan Modal Insan. Rancangan Malaysia Kesepuluh (RMKe-10), 192-251.

Kementerian Pendidikan Malaysia. (2013). Pelan Pembangunan Pendidikan Malaysia 2013-2025 :

Pendidikan Prasekolah hingga Lepasan Menengah. Kementerian Pendidikan Malaysia.

Kementerian Pendidikan Malaysia. (2015). Surat Siaran Kementerian Pendidikan Malaysia Bilangan

1 Tahun 2015: Pelaksanaan Penggunaan Pelantar Persekitaran Pembelajaran Maya

1BestariNet Kementerian Pendidikan Malaysia (KPM) (pp. 1-3).

Mahmood, H. (2005). Kepemimpinan Profesionalisme : Satu Utopia? Pemimpin, 5, 39-51.

Mohiddin, U. S., \& Khalid, F. (2014). Tahap Pengetahuan Guru Sekolah Rendah dalam Penggunaan

VLE Frog untuk Pengajaran \& Pembelajaran. The 4th International Conference on Learner Diversity, 50(2), 780-788.

Murat, N. C., Din, R., \& Daud, M. Y. (2017). Kesediaan Guru Dalam Penggunaan Media Pengajaran FROG VLE : Kajian Di Negeri Perak. In Mohd Jasmy Abd Rahman, Md Yusoff Daud, Mohd Khalid Mohd Nasir, M. H. Norman, \& Norazani Md Zain (Eds.), Promosi Tekno Media (pp. 42-50).

Fakulti Pendidikan UKM.

Mustafa, S. I. S., \& Miskon, A. S. (2011). Pengantar Pendidikan. Penerbitan Multimedia Sdn. Bhd.

Noornajihan Jaafar, \& Ab.Halim Tamuri. (2013). Hubungan Antara Efikasi Kendiri Dengan Kualiti

Guru Pendidikan Islam Sekolah Menengah Kebangsaan Malaysia. Journal of Islamic and Arabic Education, 5(1), 41-60.

Nor Azlah, M. J., \& Fariza, K. (2014). Keberkesanan Kemahiran Komunikasi Di kalangan Guru dalam Penggunaan Persekitaran Pembelajaran Maya (Frog VLE). Pengajaran Sumber Dan Teknologi Maklumat:Impaknya Ke Atas Penyelidikan Dalam Pendidikan, 63-69.

Nor, M. Y. M., \& Hussin, S. (2013). Demokrasi Pendidikan : Dilema Sekolah Kecil dan Sekolah

Berpusat. Penerbit Universiti Malaya.

Peng, C. A., Soon, V. K. L., \& Daud, S. M. (2016). Teachers' Beliefs and TPACK Toward Frog VLE Integration in Special Education (Hearing Impairment) Classroom. Conference: Conference: International Conference On Teacher Learning and Development, 2-20.

Tschannen Moran, M., \& Gareis, C. R. (2004). Principle's Sense Of Efficacy : Assesing A Promosing Construct. Journal of Educational Administration, 42(5), 573-585.

Vagias, W. M. (2006). Likert-Type Scale Response Anchors (C. I. I. F. T. \& R. Development (ed.)). 